\title{
BENTUK-BENTUK DUKUNGAN SOSIAL PADA PEGAWAI NEGERI SIPIL MENJELANG MASA PENSIUN
}

\author{
Ni Kadek Widhi Dwi Sekarsari dan Luh Kadek Pande Ary Susilawati \\ Program Studi Psikologi, Fakultas Kedokteran, Universitas Udayana \\ widhi_sekarsari@yahoo.com
}

\begin{abstract}
Abstrak
Pegawai Negeri Sipil (PNS) merupakan bagian aparatur negara yang menjadi salah satu unsur terpenting dalam pemerintahan. Sebagai seorang PNS, individu wajib mengikuti aturan-aturan yang telah tercantum dalam Undangundang nomer 43 tahun 1999. Pemberhentian atau pensiun merupakan salah satu aturan yang berlaku bagi setiap anggota PNS. Pemberhentian atau pensiun PNS adalah masa ketika seseorang diberhentikan dari pekerjaan sesuai batas usia yang telah ditetapkan dalam Peraturan Pemerintah (Dewi, 2011). Masa pensiun akan sangat berhubungan dengan siap atau tidak siapnya PNS ketika memasuki fase tersebut. Berdasarkan hal ini, peneliti tertarik untuk melihat bentuk dukungan sosial yang dibutuhkan PNS dan persiapan-persiapan yang sangat membutuhkan dukungan sosial pada PNS menjelang masa pensiun.

Penelitian ini menggunakan metode penelitian kualitatif dengan pendekatan fenomenologi. Responden dalam penelitian ini berjumlah empat orang yang berstatus sebagai PNS di Provinsi Bali. Teknik pengumpulan data yang digunakan dalam penelitian ini adalah wawancara dan observasi.

Hasil dari penelitian ini menunjukkan bahwa PNS yang akan memasuki masa pensiun membutuhkan dukungan baik dari keluarga, rekan kerja, serta instansi. Dukungan yang berasal dari keluarga merupakan dukungan paling utama yang dibutuhkan PNS menjelang masa pensiun yaitu dalam bentuk dukungan emosional dan dukungan informasi. Selain itu, persiapan-persiapan membutuhkan dukungan sosial pada PNS menjelang masa pensiun meliputi persiapan keuangan, kesehatan atau kebugaran, penyesuaian peran, kegiatan waktu luang, serta asuransi kesehatan.
\end{abstract}

Kata kunci : pegawai negeri sipil, dukungan sosial, masa pension

\begin{abstract}
Civil Servant (PNS) is part of the state apparatus that became one of the most important elements in the government. As a civil servant, people must be follow the rule included in Indonesian Regulation No. 43 Yr. 1999. Dismissal or retirement is one rule that applies to every member of civil servant. Dismissal or retirement of civil servants was a time when a person is laid off from a job appropriate age limits stipulated in Government Regulation (Dewi, 2011). Retirement would be associated with civil servant prepared or unprepared when entering that phase. Based on this, researchers are interested to see the preparations related to the readiness of civil servants towards retirement and social support necessary forms ahead of the retirement of civil servants.
\end{abstract}

This study used qualitative research methods with a phenomenological approach. Respondents in this study were four people whose status as civil servants in the province of Bali. Data collection techniques used in this study were interviews and observation.

The results of this study indicate that the civil servants who will retire requires good support from family, coworkers, as well as institutions. Support from family is the most important support is needed before the retirement of civil servants in the types of emotional support and information support. In addition, preparations are need of social support in the civil servants towards retirement include the preparation of financial, health or fitness, role adjustment, leisure time activities, as well as health insurance.

Keywords: civil servants, social support, retirement 


\section{LATAR BELAKANG}

Pegawai Negeri Sipil (PNS) merupakan bagian aparatur negara yang menjadi salah satu unsur terpenting dalam pemerintahan. PNS menjadi salah satu profesi yang paling dicari oleh masyarakat. Keuntungan yang diperoleh ketika menjadi seorang PNS mengakibatkan meningkatnya jumlah pelamar calon pegawai negeri sipil (CPNS) setiap tahun. Hal ini ditunjukkan pada peningkatan jumlah pelamar CPNS di provinsi Bali yang mencapai angka 1.591 orang, dengan jumlah CPNS yang diterima sebanyak 43 orang di lingkungan pemerintah provinsi Bali. Dapat terlihat bahwa perbandingan antara jumlah CPNS yang diterima dengan jumlah pelamar CPNS mencapai angka 1 : 37 (Nopariawan, 2014). Hal ini sejalan dengan pernyataan yang mengatakan bahwa seorang PNS akan mendapatkan kemudahan dalam mengakses dunia perbankan, memiliki tuntutan pekerjaan yang rendah, tidak adanya target pencapaian kerja di tiap bulan, serta pendapatan/gaji yang diperoleh PNS tidak bergantung dari kinerja selama satu bulan (beritametro, 2013). Berdasarkan hasil preliminary study yang dilakukan peneliti melalui wawancara informal dengan PNS secara acak, keputusan untuk menjadi seorang PNS dengan mengabdi kepada negara dikarenakan dari segi sosial ekonomi cenderung terjamin dan mendapatkan kenyaman dalam bekerja tanpa harus mengejar target tertentu.

Menurut pasal 1 undang-undang nomor 43 tahun 1999 pegawai negeri adalah setiap warga Negara Indonesia yang telah memenuhi syarat yang ditentukan, diangkat oleh pejabat yang berwenang dan diberikan tugas dalam suatu jabatan negeri, atau diberikan tugas Negara lainnya, dan diberikan gaji berdasarkan peraturan perundang-undangan yang berlaku. Adapun tugas dari seorang PNS menurut pasal 3 undang-undang nomor 43 tahun 1999 yaitu pegawai negeri yang berkedudukan sebagai unsur aparatur negara yang bertugas untuk memberikan pelayanan kepada masyarakat secara profesional, jujur, adil, dan merata dalam penyelenggaraan tugas negara, pemerintahan dan pembangunan.

Menurut data badan kepegawaian negara (BKN) tercatat ada 4.522.221 penduduk Indonesia berprofesi sebagai PNS. Proporsi jumlah PNS laki-laki yaitu 2.369.690 orang dan PNS perempuan yaitu 2.152.521 orang (BKN, 2013). Khususnya di Bali, jumlah PNS yang tercatat berada di lingkungan pemerintah provinsi Bali telah mencapai angka 6.550 orang dengan jumlah proporsi laki-laki sebanyak 3.951 orang dan perempuan sebanyak 2.599 orang (BPS, 2013).

Banyaknya jumlah PNS sangat berpengaruh terhadap produktivitas kerja PNS. Hal ini sesuai dengan pernyataan Syafrudin (2012) yang memaparkan bahwa terdapat 6 faktor penyebab menurunnya produktivitas PNS, salah satu diantaranya adalah jumlah PNS yang terlalu besar. Jumlah
PNS yang terlalu besar berpengaruh secara signifikan terhadap produktivitas PNS, sebagai contoh jika pekerjaan yang seharusnya dapat dikerjakan oleh seorang PNS namun karena jumlah PNS yang terlalu besar maka pekerjaan tersebut dikerjakan oleh 4 orang. Jika dilihat dari segi pekerjaan, maka pekerjaan tersebut akan terlihat lebih ringan namun dari segi produktivitas pegawai akan terlihat lebih rendah (Syafrudin, 2012).

Produktivitas kerja PNS akan berpengaruh terhadap prestasi kerja selama menjalankan tugas sebagai aparatur negara. PNS yang memiliki prestasi kerja selama menjalankan tugas, maka akan memperoleh penghargaan dari pihak instansi. Adapun penghargaan yang tercatat dalam pedoman manajemen PNS meliputi kenaikan pangkat, pengangkatan dalam jabatan baik jabatan struktural maupun jabatan fungsional, tanda kehormatan satya lancana karya satya terkait dengan masa kerja (10 tahun, 20 tahun, dan 30 tahun), tunjangan jabatan, tunjangan umum, kenaikan gaji secara berkala, gaji serta gaji ke-13, cuti hingga pensiun. Selain itu, pelanggaran-pelanggaran yang dilakukan juga diatur dalam pedoman manajemen PNS. Pelanggaran yang dimaksud meliputi pelanggaran kode etik berupa sanksi moral, pelanggaran disiplin, pelanggaran ijin perkawinan dan perceraian PNS, larangan PNS menjadi anggota partai politik, hingga pemberhentian baik pemberhentian dengan hormat serta pemberhentian tidak dengan hormat sebagai PNS (BKN, 2013).

Pedoman manajemen PNS juga memaparkan berbagai hal terkait dengan PNS mulai dari kepegawaian, pengadaan PNS, formasi PNS, larangan menjadi anggota partai, pernikahan PNS, kenaikan pangkat PNS, disiplin PNS, penilaian kinerja PNS, pengangkatan dalam jabatan struktural, pengangkatan dalam jabatan fungsional, moral etika PNS, korps PNS, anggaran korps PNS, hingga pemberhentian atau pensiun PNS (BKN, 2013).

Pemberhentian atau pensiun PNS adalah masa ketika seseorang diberhentikan dari pekerjaan sesuai batas usia yang telah ditetapkan dalam Peraturan Pemerintah (Dewi, 2011). Sesuai yang telah ditetapkan dalam Peraturan Pemerintah nomor 32 tahun 1979 yakni batas usia pensiun PNS adalah 56 tahun. Pada tahun 2013 terjadi perubahan batas usia pensiun PNS yang tercantum pada Peraturan Pemerintah Republik Indonesia. Perubahan usia pensiun PNS ditetapkan dalam Peraturan Pemerintah menjadi 58 tahun. Selain itu, terdapat perpanjangan usia pensiun yang terbagi menjadi tiga bagian yaitu (a) perpanjangan batas usia pensiun sampai 65 tahun untuk PNS yang memegang jabatan peneliti madya dan peneliti utama dengan tugas secara penuh di bidang penelitian, jabatan hakim pada Mahkamah Pelayaran atau jabatan lain yang ditentukan oleh Presiden, (b) usia pensiun 60 tahun untuk PNS yang memegang jabatan struktural eselon I, jabatan struktural eselon II, jabatan dokter yang ditugaskan secara 
penuh pada unit pelayanan kesehatan negeri, serta jabatan pengawas sekolah menengah atas, sekolah menengah pertama, sekolah dasar, taman kanak-kanak atau jabatan lain yang sederajat, dan jabatan lain yang ditentukan oleh Presiden, (c) usia pensiun 58 tahun untuk PNS yang memangku jabatan lain yang ditentukan oleh presiden (BKN, 2013).

Pemberhentian atau pensiun merupakan hal yang sangat penting terkait dengan hak yang akan diterima oleh seorang mantan anggota PNS. Pemberhentian atau pensiun PNS terbagi menjadi dua yaitu pemberhentian dengan hormat sebagai PNS dan pemberhentian tidak dengan hormat sebagai PNS. Secara spesifik dijelaskan pada pasal 23 undang-undang nomor 43 tahun 1999 yakni pemberhentian dengan hormat sebagai PNS dapat terjadi karena meninggal dunia, atas permintaan sendiri, mencapai batas usia pensiun, perampingan organisasi pemerintahan, serta tidak cakap jasmani dan rohani sehingga tidak dapat menjalankan kewajiban sebagai PNS. Pemberhentian tidak dengan hormat sebagai PNS dapat terjadi karena melanggar sumpah/janji PNS dan sumpah/janji jabatan, melakukan penyelewengan terhadap ideologi negara, Pancasila, Undang-Undang Dasar 1945, atau terlibat dalam kegiatan yang menentang negara dan pemerintahan serta dihukum penjara atau kurungan berdasarkan putusan pengadilan yang telah mempunyai kekuatan hukum yang tetap. Pemberhentian dengan hormat sebagai PNS memiliki hak atas pensiun, namun pemberhentian tidak dengan hormat sebagai PNS akan kehilangan hak atas pensiun (BKN, 2013).

Berdasarkan hasil pre-eleminary study melalui wawancara informal yang dilakukan terhadap dua orang PNS, didapatkan informasi bahwa responden sudah mengetahui secara detail mengenai usia pensiun PNS yang mengalami perpanjangan menjadi 58 tahun melalui surat edaran yang diberikan oleh instansi. Responden memberikan tanggapan yang berbedabeda terkait dengan perpanjangan usia pensiun yakni ada yang menerima, namun ada juga yang merasa keberatan. Responden tetap berpendapat bahwa usia pensiun PNS sudah diatur dalam Peraturan Pemerintah maupun Undang-Undang jadi sebagai pegawai, responden hanya menjalani aturan tersebut. Terkait dengan perpanjangan usia pensiun PNS, responden menunjukkan sikap menerima atas perubahan aturan mengenai usia pensiun PNS serta responden berpendapat bahwa perpanjangan usia pensiun PNS tidak memiliki pengaruh yang signifikan terhadap pekerjaan yang sedang dijalani. Hal ini dikarenakan responden sudah siap akan datangnya masa pensiun sehingga responden mengatakan bahwa lebih baik memikirkan hal apa yang akan dilakukan setelah pensiun.

Masa pensiun akan sangat berhubungan dengan siap atau tidak siapnya PNS ketika memasuki fase pensiun. Hal ini dikarenakan sebagai seorang pensiunan akan memiliki beberapa masalah terkait dengan pekerjaan setelah memasuki masa pensiun, diantaranya yaitu kehilangan kesibukan kerja, pendapatan berkurang, kehilangan fasilitas yang pernah diterima, kontak sosial dengan teman kerja atau relasi mulai berkurang, memiliki banyak waktu luang, penyesuaian diri dengan situasi baru, serta kesepian (Suardiman, 2011). Banyak kasus yang menyebutkan bahwa pensiunan akan langsung jatuh sakit hingga mengalami stroke karena kaget dengan fase yang akan individu hadapi yakni kehidupan setelah pensiun (Dewi, 2011). Salah satu media online mengabarkan bahwa setidaknya ada tiga PNS per hari yang dilarikan ke poli jiwa menjelang pensiun. Hal ini dikarenakan PNS mengalami gangguan penyesuaian terkait dengan faktor ekonomi karena terjadi perbedaan pendapatan yang diterima ketika masih bekerja dan tidak bekerja (Kabartop, 2012).

Kecemasan yang berlebihan diakibatkan aktualisasi diri karena merasa tidak dihargai dan tidak dapat lagi memenuhi kebutuhan keluarga, susah tidur, perasaan sedih, mudah lelah serta mulai mengeluhkan penyakit-penyakit fisik merupakan ciri dari gangguan penyesuaian yang dialami oleh PNS menjelang masa pensiun. Apabila hal ini tidak ditangani secara serius oleh pihak keluarga, maka hal ini akan berakibat depresi pada PNS karena ketidaksiapan memasuki masa pensiun. Kristiono (2011) menyebutkan ada dua faktor yang menyebabkan kecemasan pada PNS menjelang masa pensiun yaitu faktor individu itu sendiri dan faktor lingkungan. Faktor individu meliputi perasaan kurang percaya diri, masa depan tanpa tujuan dan perasaan ketidakmampuan dalam bekerja, sedangkan faktor lingkungan meliputi perasaan tidak dicintai orang lain, tidak memiliki kasih sayang, dan tidak mendapat dukungan atau motivasi dari orang lain.

Tidak semua PNS mengalami kecemasan ketika memasuki masa pensiun dikarenakan PNS sudah mempersiapkan diri serta telah menyadari bahwa profesi sebagai PNS merupakan kondisi fisik yang digunakan untuk bekerja dalam batasan usia tertentu. Hal ini mengakibatkan PNS menyadari bahwa semakin tua individu tentu akan diikuti juga dengan penurunan pada kondisi fisik sehingga berpengaruh pada penurunan produktivitas kerja PNS. Seiring dengan pertambahan usia dan penurunan produktivitas kerja, PNS akan mengalami fase berhenti bekerja atau pensiun (Rio, 2013). Salah satu penelitian yang dilakukan oleh Imama (2011) menyebutkan bahwa dukungan sosial memiliki hubungan yang signifikan terhadap kecemasan ketika memasuki masa pensiun, yang berarti bahwa semakin besar dukungan sosial yang dimiliki individu maka kecemasan yang dialami ketika memasuki masa pensiun akan menurun.

Pada keadaan PNS yang akan memasuki masa pensiun dibutuhkan dukungan sosial bagi PNS baik dari keluarga, rekan kerja maupun instansi untuk membantu PNS mempersiapkan masa pensiun yang terencana dan terhindarkan dari konflik serta menghindarkan dari ketidaksiapan yang berdampak pada kecemasan yang berlebihan hingga depresi. Murtiningrum (2005) menjelaskan dukungan sosial sebagai model dukungan yang dihasilkan dari 
interaksi antar pribadi yang melibatkan aspek emosi, penilaian, informasi dan instrumen sehingga dapat mengurangi beban yang diterima individu. Individu sebagai makhluk sosial penting untuk dapat berinteraksi dengan individu lain. Individu yang dapat berinteraksi bersama individu lain diharapkan mampu bertukar informasi serta permasalahan yang sedang dihadapi individu.

Kadarisman (2011) menyebutkan bahwa dukungan dari significant other pada PNS yang memasuki masa pensiun akan membuat PNS merasa dicintai, diperhatikan, serta tidak merasa sendirian ketika menghadapi masa tersebut. Sama halnya dengan PNS, dukungan sosial sangat diperlukan terutama ketika PNS akan memasuki masa pensiun karena pada masa ini tekanan psikologis akan semakin meningkat. Hurlock (2006) menyebutkan bahwa salah satu tekanan psikologis yang dialami oleh individu yang akan memasuki masa pensiun adalah perubahan peran, sehingga individu perlu untuk mengubah gaya hidup dan menjalankan peran baru.

Hal ini sejalan dengan pernyataan yang dikemukakan oleh Rio (2013) bahwa PNS yang akan memasuki fase pensiun penting untuk mempersiapkan diri melalui beberapa cara sebagai berikut : 1) PNS harus selalu bersyukur sehingga akan memberikan dampak positif pada kesehatan dan suasana hati; 2) menerapkan gaya hidup yang sehat sehingga PNS tidak mengalami kekosongan waktu dan kehilangan kegiatan; 3) merencanakan keuangan keluarga dikarenakan akan terjadi perbedaan pendapatan yang diterima ketika pensiun; 5) menjaga hubungan baik dengan teman sejawat sehingga pada masa pensiun kegiatan atau aktivitas nonformal secara bersama; 6) memperdalam sisi spiritual, diharapkan PNS dapat mengisi waktu luang dengan kegiatan rohani serta aktivitas sosial sehingga memberikan ketenangan dan ketentraman secara psikis serta batin.

PNS menjelang masa pensiun, membutuhkan dukungan sosial dari lingkungan dalam membantu mempersiapkan masa pensiun yang terencana dan terhindarkan dari konflik. Berdasarkan hal yang telah dipaparkan, maka pertanyaan dalam penelitian adalah bentukbentuk dukungan sosial apa yang dibutuhkan PNS menjelang masa pensiun? dan persiapan-persiapan PNS menjelang masa pensiun yang membutuhkan dukungan sosial?

\section{METODE}

\section{Tipe penelitian}

Metode yang digunakan dalam penelitian ini adalah metode penelitian kualitatif. Menurut Tohirin (2012) metode penelitian kualitatif yaitu pengumpulan data pada suatu latar alamiah, dengan menggunakan metode alamiah, dan dilakukan oleh orang atau peneliti yang tertarik secara alamiah. Metode penelitian kualitatif digunakan untuk dapat memahami suatu fenomena secara mendalam yaitu meneliti sesuatu dari segi proses serta menemukan perspektif baru tentang suatu fenomena dari responden penelitian. Adapun karakteristik metode penelitian kualitatif menurut Tohirin (2012) meliputi : berfokus pada kata, menuntut keterlibatan peneliti (partisipatif), dipengaruhi sudut pandang partisipan (orang yang menjadi sumber data), fokus penelitian yang holistik, desain dan penelitiannya bersifat fleksibel, lebih mengutamakan proses daripada hasil, menggunakan latar alami, serta menggunakan analisis induktif kemudian dilanjutkan dengan deduktif.

Desain yang digunakan dalam penelitian ini adalah fenomenologi. Pendekatan fenomenologi berfokus pada pengalaman subjektif yang dialami atau dirasakan oleh responden penelitian tentang suatu fenomena atau peristiwa. Penelitian ini berusaha memahami terkait dengan bentuk dukungan sosial yang dibutuhkan pada PNS menjelang masa pensiun dan persiapan-persiapan dilakukan PNS menjelang masa pensiun yang sangat membutuhkan dukungan sosial.

\section{Karakteristik responden}

Penelitian ini menggunakan 4 orang sebagai responden penelitian yang berstatus sebagai PNS di lingkungan Provinsi Bali. Jenis kelamin responden tidak menjadi batasan dalam penelitian ini baik laki-laki maupun perempuan, namun faktor usia menjadi salah satu karakteristik utama dalam pemilihan responden penelitian. Batas usia responden dalam penelitian ini adalah 55-56 tahun yakni dua tahun sebelum memasuki masa pensiun, hal ini disesuaikan dengan fokus penelitian yaitu bentuk dukungan sosial yang dibutuhkan PNS menjelang masa pensiun dan persiapan apa yang dilakukan PNS menjelang masa pensiun yang sangat membutuhkan dukungan sosial. Berikut gambaran karakteristik keempat responden dalam penelitian yaitu :

Tabel 1.

\section{Karakteristik Responden Penelitian}

\begin{tabular}{ll}
\hline \multicolumn{2}{c}{ Karakteristik Responden Penelitian } \\
\hline Responden Wnt (R1) & Responden Ntr (R3) \\
Usia : 56 tahun & Usia : 55 tahun 6 bulan \\
Jenis Kelamin : Perempuan & Jenis kelamin : Laki-laki \\
Jabatan : Kepala Seksi & Jabatan : Pembantu pimpinan \\
Lama bekerja : 34 tahun & Lama bekerja : 33 tahun \\
& \\
Responden Wda (R2) & Responden Adn (R4) \\
Usia : 56 tahun & Usia : 56 tahun \\
Jenis Kelamin : Perempuan & Jenis kelamin : Perempuan \\
Jabatan : Staff & Jabatan : Pelaksana \\
Lama bekerja : 33 tahun & Lama bekerja : 32 tahun \\
\hline
\end{tabular}

\section{Lokasi pengumpulan data}


Lokasi pengumpalan data dalam penelitian terkait dengan PNS menjelang masa pensiun dilakukan pada dua instansi yang berbeda. Instansi pertama yang menjadi lokasi pengumpulan data adalah Dinas Pendidikan Pemuda dan Olahraga (Disdikpora) Provinsi Bali. Disdikpora Provinsi Bali dipilih karena telah memperoleh data dari Badan Kepegawaian Daerah (BKD) Provinsi Bali bahwa Disdikpora merupakan salah satu instansi Pemerintah yang memiliki PNS menjelang masa pensiun atau sesuai dengan karakteristik dari responden penelitian.

Instansi kedua yang menjadi lokasi pengumpulan data adalah Universitas Udayana. Instansi ini dipilih dikarenakan telah mengajukan surat permohonan melakukan pengumpulan data dan mendapatkan persetujuan serta identitas dari calon responden penelitian berupa nama serta nomer telepon.

\section{Teknik pengumpulan data}

\section{Pengumpulan data dengan wawancara}

'Teknik wawancara yang digunakan adalah wawancara semi terstruktur dan proses wawancara yang tidak bersifat kaku sehingga memperoleh data secara mendalam. Pelaksanaan wawancara dilakukan dengan menggunakan alat perekam berupa handphone Samsung seri GT-18262. Sebelum proses wawancara dimulai, responden penelitian diminta kesediaannya untuk mengikuti semua proses penelitian yang tertuang dalam inform consent yang telah disiapkan.

'Proses wawancara pada keempat responden dilakukan mulai bulan Mei hingga Agustus 2014. Wawancara dilakukan sebanyak sebelas kali pada keempat responden. Hasil wawancara pada kedua responden kemudian ditulis dalam bentuk verbatim dan fieldnote wawancara penelitian.

\section{Pengumpulan data dengan observasi}

'Pelaksanaan observasi dilakukan selama proses wawancara berlangsung dengan responden penelitian. Keseluruhan hasil observasi dicatat dalam bentuk filednote (catatan lapangan) yang dibuat sesaat setelah proses observasi dan wawancara berakhir, sehingga mendapatkan catatan-catatan penting terkait dengan perilaku responden selama proses pengamatan dan wawancara dalam kaitannya dengan bentuk dukungan sosial yang dibutuhkan PNS menjelang masa pensiun dan persiapan apa yang dilakukan PNS menjelang masa pensiun yang sangat membutuhkan dukungan sosial. Observasi dilakukan sebanyak sebelas kali.

\section{Analisa data}

Teknik analisis data yang digunakan dalam penelitian ini adalah metode grounded theory. Strauss dan Corbin (2003) menjelaskan bahwa metode grounded theory merupakan proses analisis yang mengidentifikasi dan menyusun konsep berdasarkan sifat dan ukurannya. Menurut Strauss dan Corbin (2003) terdapat tiga langkah yang dilakukan dalam melakukan analisis data yaitu open coding, axial coding, dan selective coding.

Pada tahapan open coding, dimulai dengan melakukan koding atau memberikan koding pada seluruh data yang didapatkan baik melalui verbatim wawancara dan fieldnote. Proses ini berlaku pada setiap data responden maupun informan, kemudian diurutkan dalam sebuah sistem koding.

Pada tahapan axial coding, dimulai dengan memilih serta mengelompokkan pada kategori-kategori dan menempatkannya dalam suatu model teoretis. Tahapan axial coding mulai membuat kaitan antar kategori berdasarkan hasil temuan yang diperoleh pada tahapan open coding.

Pada tahapan selective coding, dimulai dengan merangkai sebuah cerita dari hubungan antar kategori-kategori dan memiliki hasil kategorisasi dalam proses axial coding yang disesuaikan dengan tujuan penelitian. Pada tahap ini menghasilkan satu tema besar yang akan dipaparkan dalam sub bab hasil penelitian dan akan dibahas dalam sub bab pembahasan.

Teknik pemantapan kredibilitas data penelitian

Menurut Moleong (2004) ada beberapa teknik yang dapat digunakan untuk meningkatkan kredibilitas atau keabsahan data, namun dalam penelitian menggunakan tiga teknik diantaranya adalah ketekunan atau keajegan pengamatan, triangulasi (sumber dan metode), dan pemeriksaan sejawat melalui diskusi.

\section{Isu etika penelitian}

Adapun beberapa isu etika yang peneliti harus perhatikan dalam penelitian ini dan disampaikan kepada responden maupun informan penelitian adalah terkait dengan persetujuan individu untuk menjadi responden penelitian, terkait dengan kerahasiaan informasi yang diberikan responden kepada peneliti, tidak merugikan atau membahayakan responden penelitian, terkait dengan menjaga atau menyimpan rekaman hasil wawancara, dan responden penelitian memiliki hak untuk mundur di tengah-tengah penelitian.

\section{HASIL PENELITIAN}

Pada sub bab hasil penelitian, diperoleh satu tema utama yaitu bentuk dukungan sosial yang dibutuhkan PNS menjelang masa pensiun. Selain itu, dalam penelitian juga ditemukan bahwa persiapan-persiapan PNS menjelang masa pensiun merupakan salah satu bagian yang membutuhkan dukungan sosial dari lingkungan seperti keluarga, rekan kerja, dan instansi. Berikut merupakan hasil penelitian yang 
diperoleh dari keempat responden dan informan yang akan jabarkan sesuai dengan urutan dari keempat responden.

\section{Bentuk-bentuk dukungan sosial yang dibutuhkan PNS menjelang masa pension}

\section{Dukungan keluarga}

Pada responden pertama, terlihat bahwa menjelang masa pensiun keluarga seperti orangtua dan suami memberikan dukungan berupa saran atau masukan kepada responden terkait dengan permasalahan yang sedang dihadapi responden di kantor. Selain itu, responden menyatakan bahwa membutuhkan dukungan dari keluarga khususnya dukungan dari suami agar suami lebih berinisitif memberikan saran atau masukan kepada responden tanpa harus diminta oleh responden.

Pada responden kedua, responden mengatakan bahwa keluarga memberikan dukungan dengan cara menjaga perasaan responden agar tetap senang dan saling memaklumi dengan menantu agar tidak muncul perasaan tersinggung antara satu dan lainnya. Responden menjelaskan bahwa membutuhkan dukungan dari keluarga berupa perhatian dari anak sebagai contoh saat menderita sakit responden menginginkan agar anak-anak dapat mengantarkan responden ke dokter, kondisi keluarga yang saling mengisi, kenyamanan dalam keluarga, keluarga tetap rukun, serta suasana nyaman dan tenang di rumah.

Pada responden ketiga, responden mendapat dukungan dari anak berupa masukan agar responden tidak bekerja kembali dan lebih menikmati hidup. Hal ini dipertegas dengan masukan dari informan yang mengungkapkan agar responden lebih mengatur pola hidup sehat dan tenang dalam menjalani hidup ke depan. Keluarga juga memberikan dukungan secara emosional kepada responden menjelang masa pensiun berupa perasaan diperhatikan oleh anak, kebersamaan responden dengan istri, serta keluarga yang tidak menuntut apa-apa dari responden. Selain itu, responden menambahkan bahwa membutuhkan dukungan dari keluarga dalam bentuk perhatian dari anak ke orangtua, anak-anak bisa menjenguk responden ketika sakit, serta keluarga yang tetap mendukung rencana kegiatan responden setelah pensiun dan tidak menuntut apa-apa dari responden.

Pada responden keempat, dukungan yang diberikan kepada responden menjelang masa pensiun dari suami berupa saran atau masukan kepada responden untuk beristirahat. Anak dari responden juga memberikan saran atau masukan agar responden beristirahat dan tidak beban dalam menjalani hidup setelah pensiun serta anak-anak menyarankan agar responden tetap menekuni usaha banten yang sudah dijalankan responden saat ini. Responden menambahkan bahwa menjelang masa pensiun, responden membutuhkan dukungan dari keluarga dalam bentuk dukungan emosional berupa kondisi keluarga yang saling mengisi, kondisi keluarga yang tetap rukun serta suasana nyaman dan tenang di rumah.

\section{Dukungan rekan kerja}

Pada responden pertama, dukungan yang diterima responden dari rekan kerja menjelang masa pensiun berupa informasi mengenai pembekalan dari pihak instansi serta informan memberikan dukungan kepada responden yang akan memasuki masa pensiun berupa semangat atau dorongan agar responden lebih memperhatikan kesehatan.

Pada responden kedua, dukungan yang diterima responden dari rekan kerja menjelang masa pensiun berupa saran atau masukan kepada responden untuk mencari hiburan seperti berhias diri agar responden tidak cepat tua. Informan juga menambahkan bahwa semua PNS akan menuju pada tahap pensiun namun hanya berbeda waktu, jadi responden harus tetap menjalani masa pensiun.

Pada responden ketiga, terkait dengan masa pensiun rekan kerja memberikan dukungan dalam bentuk saran atau masukan kepada responden untuk kembali bekerja pada instansi sebagai pegawai kontrak.

Pada responden keempat, rekan kerja memberikan dukungan dalam bentuk saran atau masukan kepada responden ketika pensiun agar dapat berkunjung ke kantor untuk tetap bertemu. Informan juga memberikan saran atau masukan agar responden tetap melakukan kegiatan sesuai kemampuan pada saat masa pensiun. Selain itu, responden membutuhkan dukungan dari rekan kerja berupa motivasi atau dorongan seperti motivasi untuk menjaga kesehatan dan mengatur pola makan pada masa pensiun.

\section{Dukungan instansi}

Pada responden pertama, dukungan yang diberikan pihak instansi menjelang masa pensiun seperti membuat acara perpisahan bagi seluruh anggota PNS yang akan pensiun, pembekalan atau pelatihan menuju tahap pensiun kepada seluruh anggota PNS, serta pihak koperasi memberikan dukungan berupa saran atau masukan mengenai cara-cara untuk berbisnis setelah pensiun.

Pada responden kedua, dukungan yang diterima responden dari pihak instansi berupa pemberian kenangkenangan kepada seluruh pegawai yang memasuki masa pensiun. Pemberian kenang-kenangan ini digunakan sebagai ucapan terimakasih atas pengabdian pegawai selama bekerja pada instansi. Selain itu, responden juga menerima dukungan berupa pembekalan atau pelatihan menuju tahap pensiun.

Pada responden ketiga, dukungan yang diberikan pihak instansi yang akan memasuki masa pensiun berupa pembekalan atau pelatihan, namun pembekalan atau pelatihan diberikan oleh pihak instansi kepada beberapa orang yang telah dipilih untuk mengikuti kegiatan sesuai dengan jumlah yang sudah ditentukan sebelumnya dan tidak semua pegawai 
yang akan memasuki masa pensiun dapat mengikuti pembekalan atau pelatihan.

Pada responden keempat, dukungan yang diterima responden dari pihak instansi menjelang masa pensiun yaitu berupa pemberian kenang-kenangan kepada setiap pegawai yang akan menuju pada masa pensiun. Pemberian kenangkenangan dari pihak instansi kepada setiap pegawai yang akan menuju masa pensiun digunakan sebagai ucapan terimakasih atas pengabdian selama bekerja di instansi. Selain itu, responden juga membutuhkan dukungan dari pihak instansi berupa dukungan secara moral yang dapat diberikan kepada setiap pegawai yang akan memasuki masa pensiun.

Persiapan-persiapan yang membutuhkan dukungan sosial pada PNS menjelang masa pension

\section{Persiapan Keuangan}

Pada responden pertama, cara yang dilakukan untuk mempersiapkan keuangan sebelum memasuki masa pensiun yaitu dengan mengembangkan usaha kantin di kantor. Usaha kantin sudah berjalan tujuh tahun dan responden dibantu oleh dua orang karyawan dalam mengembangkan usaha kantin. Selain itu, responden memiliki rencana untuk membuat jajan kering yang dibantu oleh anak dan suami dalam proses pembuatan.

Pada responden kedua, cara yang dilakukan untuk mempersiapkan keuangan sebelum memasuki masa pensiun yaitu dengan membangun usaha rumah kos. Usaha rumah kos sudah dijalankan responden selama tiga tahun dan responden memiliki rencana untuk kembali membangun rumah kos setelah memasuki masa pensiun.

Pada responden ketiga, cara yang dilakukan untuk mempersiapkan keuangan sebelum memasuki masa pensiun yaitu dengan membangun usaha rumah kos yang sudah berjalan selama empat belas tahun. Usaha rumah kos dipersiapkan sebagai penghasilan tambahan responden setelah memasuki masa pensiun. Selain itu, setelah memasuki masa pensiun, responden memiliki rencana untuk mengembangkan usaha warung yang digunakan sebagai tempat untuk bertemu dan mengobrol dengan teman.

Pada responden keempat, cara yang dilakukan untuk mempersiapkan keuangan sebelum memasuki masa pensiun yaitu dengan berjualan banten. Responden sudah berjualan banten selama tujuh tahun dan responden memiliki rencana untuk mengikuti kursus banten setelah memasuki masa pensiun. Selain itu, setelah memasuki masa pensiun, responden memiliki rencana untuk mengembangkan bisnis simpan pinjam dan membangun usaha rumah kos.

\section{Program kesehatan atau kebugaran}

Pada responden pertama, kondisi fisik mulai mengalami penurunan yang diakibatkan oleh pertambahan usia sehingga responden mulai mengatur pola makan, mengkonsumsi vitamin, serta responden melakukan cek kesehatan rutin setiap tahun.

Pada responden kedua, program atau cara yang dilakukan untuk menjaga kesehatan adalah dengan mengikuti olahraga, mengatur pola makan, dan beristirahat, namun responden tidak melakukan cek kesehatan secara rutin.

Pada responden ketiga, program atau cara yang dilakukan untuk menjaga kesehatan adalah dengan melakukan olahraga, menjaga pikiran, dan mengatur pola makan, namun responden tidak melakukan cek kesehatan secara rutin.

Pada responden keempat, program atau cara yang dilakukan untuk menjaga kesehatan adalah dengan menjaga pola makan dan gaya hidup, mencari informasi kesehatan melalui internet, serta memperbanyak konsumsi buah-buahan. Penyesuaian peran

Pada responden pertama, penyesuaian peran yang akan dijalankan responden setelah memasuki masa pensiun yaitu responden mulai mempersiapkan mental, merubah pola pikir, mulai mengatur jadwal, serta responden tetap memiliki kesibukan setelah pensiun.

Pada responden kedua, penyesuaian peran yang akan dijalankan responden setelah memasuki masa pensiun yaitu tetap memiliki kesibukan setelah pensiun. Salah satu peran yang akan dijalankan responden adalah menjadi ibu rumah tangga dengan menjaga dan mengurus cucu di rumah.

Pada responden ketiga, penyesuaian peran yang akan dijalankan responden setelah memasuki masa pensiun yaitu tetap memiliki kesibukan setelah pensiun dengan membuka usaha warung serta mengurus cucu.

Pada responden keempat, penyesuaian peran yang akan dijalankan responden setelah memasuki masa pensiun yaitu dengan menyesuaikan diri dengan lingkungan, menjalin komunikasi dengan anak dan menantu, serta mengurus cucu. Kegiatan waktu luang

Pada responden pertama, rencana kegiatan yang akan dilakukan untuk mengisi waktu luang setelah memasuki masa pensiun adalah berkebun, memasak, mengawasi usaha kantin di kantor, serta melakukan perjalanan keluar negeri bersama suami.

Pada responden kedua, rencana kegiatan yang akan dilakukan untuk mengisi waktu luang setelah memasuki masa pensiun adalah melakukan pekerjaan rumah tangga di rumah.

Pada responden ketiga, rencana kegiatan yang akan dilakukan untuk mengisi waktu luang setelah memasuki masa pensiun adalah mengantar istri ke kantor, membuka usaha warung, melakukan olahraga sore, serta berpergian atau jalanjalan.

Pada responden keempat, rencana kegiatan yang akan dilakukan untuk mengisi waktu luang setelah memasuki masa pensiun adalah berkebun dan mengerjakan pekerjaan rumah tangga di rumah.

Asuransi kesehatan 
Sebagai PNS, keempat responden menjelaskan bahwa mengikuti jaminan kesehatan yang telah dipersiapkan oleh Pemerintah yaitu ASKES. Jaminan kesehatan berupa asuransi kesehatan untuk memudahkan responden dalam memperoleh pelayanan kesehatan.

\section{PEMBAHASAN DAN KESIMPULAN}

Berdasarkan hasil penelitian yang telah dikemukakan, PNS yang akan memasuki masa pensiun mulai menerima dan membutuhkan dukungan dari lingkungan baik dari keluarga, rekan kerja maupun instansi untuk membantu PNS menjalani masa pensiun yang baik dan terhindar dari konflik. Selain bentuk-bentuk dukungan sosial yang dibutuhkan PNS, persiapan-persiapan PNS menjelang masa pensiun merupakan salah satu bagian yang membutuhkan dukungan sosial dari keluarga, rekan kerja, dan instansi.

Bentuk-bentuk dukungan sosial yang dibutuhkan PNS menjelang masa pension

\section{Dukungan keluarga}

Keluarga merupakan dua atau lebih orang yang memiliki komitmen agar setiap orang dapat menjalin atau berbagi kedekatan, penghasilan, tanggungjawab dalam menyelesaikan permasalahan, dan nilai-nilai (Olson \& DeFrein, 2000). Dukungan sosial yang diperoleh melalui keluarga merupakan dukungan yang paling utama, hal ini disebabkan karena keluarga merupakan kelompok sosial utama yang memiliki ikatan emosi yang paling besar sehingga keluarga dapat memberikan dukungan sosial berupa saling komunikasi, mencari kesibukan hingga melakukan liburan (Azizah, 2011). Selain itu, masalah penyesuaian yang paling serius dan paling umum terjadi pada masa pensiun adalah hubungan dengan anggota keluarga sehingga dukungan yang berasal dari keluarga sangat dibutuhkan individu dalam mengahadapi masa pensiun (Hurlock, 2006). Berdasarkan uraian di atas, dapat dilihat bahwa dukungan yang dibutuhkan oleh PNS menjelang masa pensiun dari keluarga yaitu dukungan informasi dan dukungan emosional. Berikut ini gambaran bentuk dukungan sosial yang diterima dan dibutuhkan PNS dari keluarga menjelang masa pensiun :

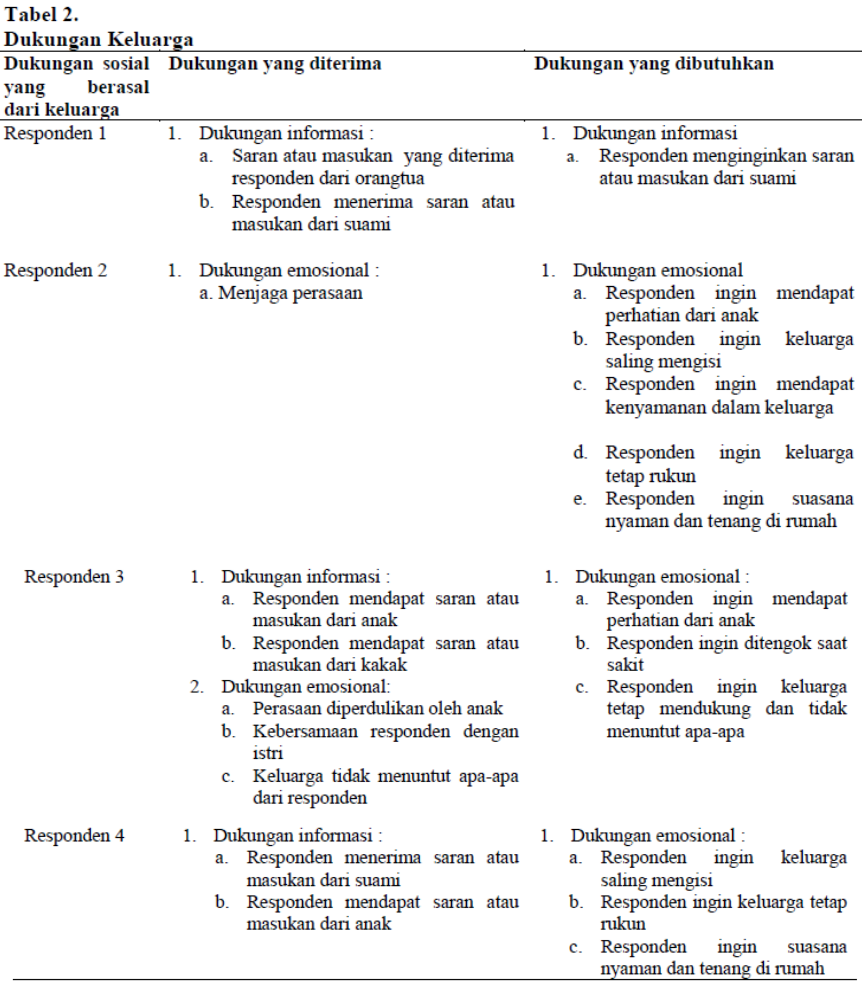

\section{Dukungan rekan kerja}

Azizah (2011) menjelaskan bahwa individu yang lebih dekat dan terbuka terhadap teman terdekat akan merasa lebih nyaman sehingga pemberian dukungan sosial dapat berupa berbagi pengalaman serta curhat. Berdasarkan hal yang telah dipaparkan, PNS yang akan memasuki masa pensiun membutuhkan dukungan dari rekan kerja berupa dukungan motivasional. Dukungan motivasional merupakan bentuk dukungan berupa pemberian dorongan serta semangat guna menyelesaikan permasalahan yang dihadapi individu (Sarafino, 1998). Berikut gambaran bentuk dukungan yang berasal dari rekan kerja yang diterima atau dibutuhkan oleh PNS menjelang masa pensiun :

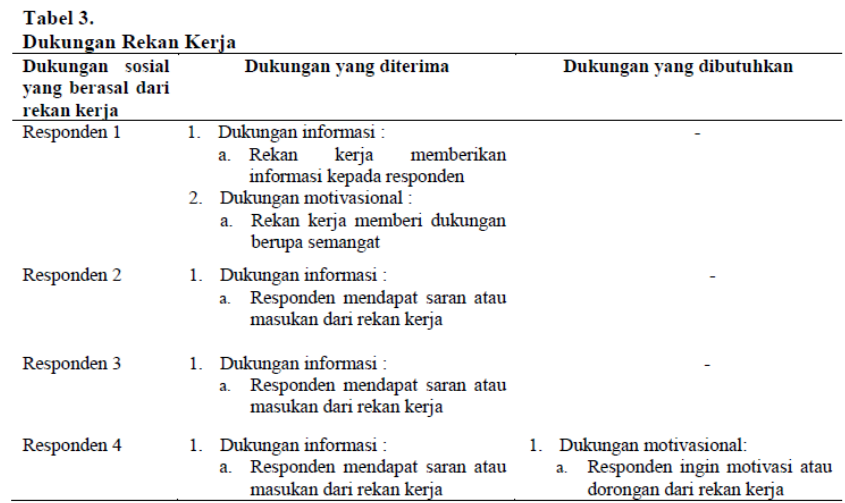

\section{Dukungan instansi}

Hurlock (2006) menjelaskan bahwa permasalahan pensiun yang utama pada suatu organisasi atau instansi adalah membuat sesuatu yang dapat menguntungkan dengan 
memberikan pendapatan yang memadai setelah pensiun. Berdasarkan hal yang telah dikemukakan, didapatkan bahwa dukungan dari pihak instansi yang dibutuhkan bagi PNS menjelang masa pensiun adalah dukungan penghargaan dan dukungan emosional. Menurut Sarafino (1998), dukungan penghargaan merupakan bentuk dukungan berupa pemberian penghargaan pada individu, dorongan terhadap perasaan individu, serta perbandingan yang positif dengan individu lainnya yang berguna untuk meningkatkan harga diri individu. Selain itu, dukungan emosional merupakan bentuk dukungan seperti membuat individu memiliki perasaan nyaman, yakin, diperdulikan, serta dicintai oleh sumber dukungan sosial sehingga individu dapat menghadapi masalah dengan baik. Berikut gambaran bentuk dukungan yang berasal dari instansi yang diterima atau dibutuhkan oleh PNS menjelang masa pensiun :

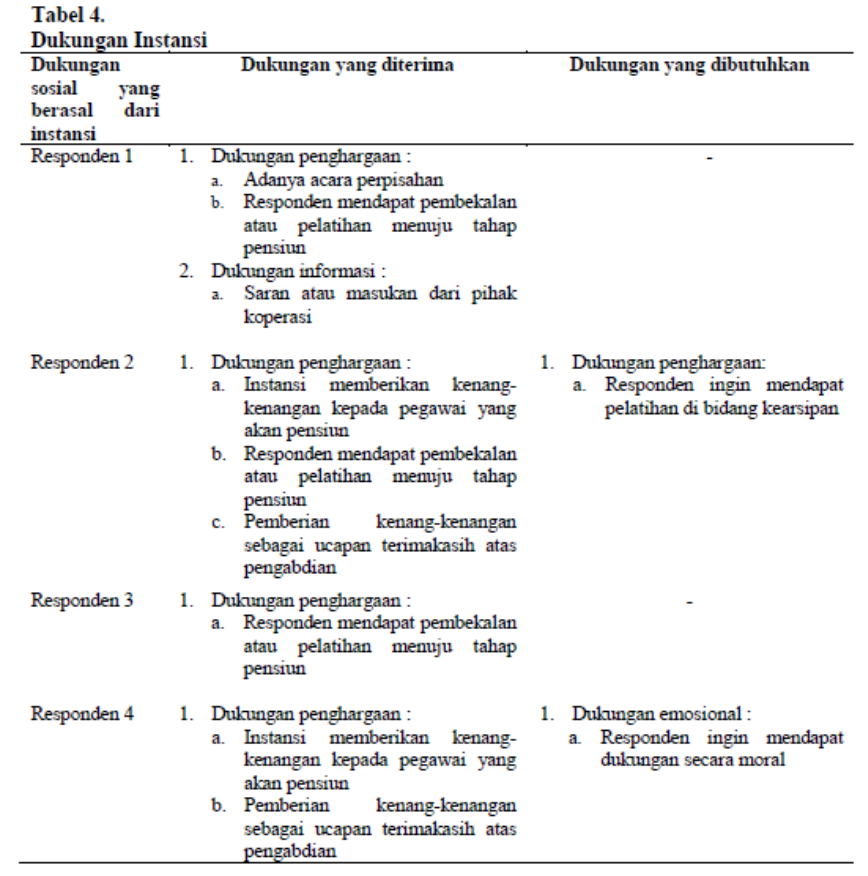

\section{Persiapan-persiapan yang membutuhkan dukungan sosial pada PNS menjelang masa pensiun}

Selain bentuk dukungan sosial yang dibutuhkan PNS, persiapan-persiapan PNS menjelang masa pensiun juga membutuhkan dukungan dari keluarga, rekan kerja, dan instansi. Hurlock (2006) menyebutkan bahwa individu pada masa dewasa madya yang telah mempersiapkan diri menghadapi masa pensiun, dapat menyesuaikan diri lebih baik terhadap hari tua dibandingkan dengan individu yang tidak melakukan persiapan menjelang masa pensiun. Hal ini sesuai dengan pernyataan Suardiman (2011) yang menjelaskan bahwa setiap individu sangat penting dalam melakukan perencanaan ketika menjelang masa pensiun dikarenakan masa pensiun akan berdampak pada hilangnya dua hal yang berkaitan dengan pekerjaan yaitu pendapatan dan status yang mengakibatkan perubahan pada banyak aspek lain. Darmojo dan Martono dalam Azizah (2011) yang menyatakan bahwa individu yang memasuki masa pensiun akan kehilangan beberapa hal terkait dengan pekerjaan antara lain kehilangan financial, kehilangan status, kehilangan teman atau kenalan, serta kehilangan kegiatan atau pekerjaan, sehingga penting bagi setiap individu yang akan memasuki masa pensiun mendapatkan dukungan dari lingkungan terkait dengan persiapan yang akan dilakukan PNS.

Persiapan keuangan

Hurlock (2006) menjelaskan bahwa individu yang berada pada masa dewasa madya kecenderungan mengalami gangguan masalah keuangan terkait dengan berakhirnya suatu pekerjaan. Kehilangan pendapatan merupakan salah satu jenis penyebab tekanan dalam keluarga pada usia dewasa madya (Olson \& DeFrain, 2000). Apsari (2012) menambahkan bahwa salah satu persiapan karyawan yang akan memasuki masa pensiun adalah persiapan ekonomi.

Pada keempat responden terlihat bahwa mempersiapkan keuangan merupakan perencanaan utama yang telah dijalankan sebelum memasuki masa pensiun. Suardiman (2011) menjelaskan bahwa persiapan keuangan bagi para pensiunan direncanakan sejak 10 atau 15 tahun sebelum memasuki masa pensiun. Persiapan keuangan pada keempat responden terhitung sejak sembilan tahun hingga enam belas tahun sebelum memasuki masa pensiun. Berikut gambaran persiapan keuangan PNS menjelang masa pensiun :

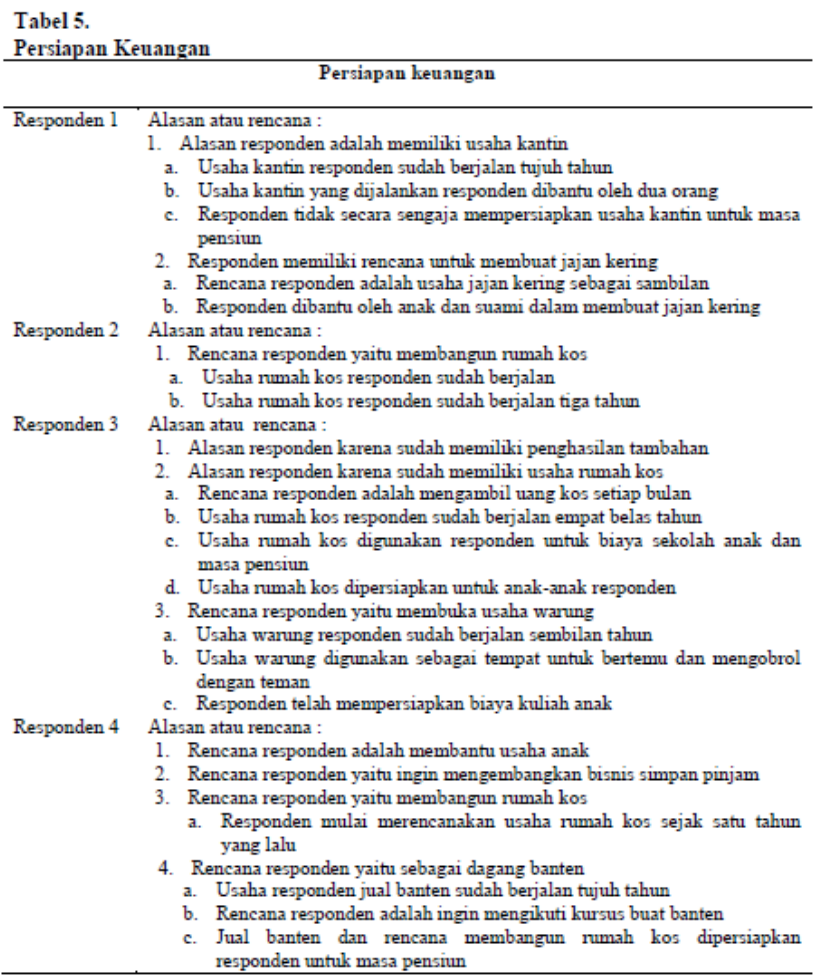

\section{Program kesehatan atau kebugaran}

Hurlock (2006) menjelaskan bahwa usia dewasa madya ditandai dengan menurunnya kesegaran fisik secara 
umum dan memburuknya kesehatan. Apsari (2012) menyatakan bahwa perlu tindakan preventif untuk menjaga kesehatan dengan melakukan pemeriksaan kesehatan di usia pensiun untuk mendeteksi adanya gangguan kesehatan yang dialami serta pentingnya menata pola makan yang tepat untuk menjaga kesehatan. Pada keempat responden yang akan memasuki masa pensiun, tergambarkan mulai memikirkan program-program atau cara-cara yang dilakukan untuk menjaga kondisi kesehatan seperti menjaga kebugaran atau kesehatan, mulai dari mengatur pola makan dan pola hidup, melakukan pemeriksaan kesehatan secara rutin, mengkonsumsi vitamin, serta melakukan olahraga. Berikut gambaran persiapan atau program-program yang dilakukan PNS untuk menjaga kondisi kesehatan menjelang masa pensiun :

Tabel 6.

Program kesehatan atau kebugaran

\begin{tabular}{|c|c|}
\hline \multicolumn{2}{|r|}{ Program kesehatan atau kebugaran } \\
\hline Responden 1 & $\begin{array}{l}\text { Alasan atau rencana : } \\
\text { 1. Alasan responden adalah penuruman fisik akibat usia bertambah } \\
\text { a. Responden menjaga pola makan dan mengkonsumsi vitamin } \\
\text { b. Responden melakukan cek kesehatan rutin setiap tahun }\end{array}$ \\
\hline Responden 2 & $\begin{array}{l}\text { Alasan atau rencana : } \\
\text { 1. Alasan responden adalah sudah tua } \\
\text { a. Mengikuti olahraga, mengatur pola makan dan beristirahat } \\
\text { b. Responden tidak melakukan cek kesehatan secara rutin }\end{array}$ \\
\hline Responden 3 & $\begin{array}{l}\text { Alasan atau rencana: } \\
\text { 1. Responden melakukan olahraga, menjaga pikiran, dan mengatur pola } \\
\text { makan } \\
\text { 2. Responden melakukan pola makan secukupnya } \\
\text { 3. Responden tidak melakukan cek kesehatan secara rutin }\end{array}$ \\
\hline Responden 4 & $\begin{array}{l}\text { Alasan atau rencana : } \\
\text { 1. Alasan responden adalah sudah tua } \\
\text { a. Responden menjaga pola makan dan pola hidup } \\
\text { b. Responden rajin membaca informasi di internet } \\
\text { c. Responden memperbanyak konsumi buah }\end{array}$ \\
\hline
\end{tabular}

\section{Penyesuaian peran}

Papalia dkk (2009) menjelaskan bahwa pada masa dewasa madya, individu akan mengalami perubahanperubahan peran sosial diantaranya individu memiliki anak, individu memiliki cucu, terjadi perubahan pekerjaan dan karir, serta pensiun. Secara spesifik Suardiman (2011), menjelaskan bahwa kondisi pensiun lebih sukar bagi individu yang menempatkan diri secara kuat terkait dengan peran kerja, sehingga penting untuk melakukan penyesuaian peran bagi individu yang akan memasuki masa pensiun. Keempat responden menyebutkan bahwa penyesuaian peran yang dilakukan terkait dengan masa pensiun adalah tetap memiliki kesibukan setelah masa pensiun seperti menjadi ibu rumah tangga, mengurus cucu, serta melanjutkan dan mengawasi usaha. Berikut gambaran penyesuaian peran PNS menjelang masa pensiun :
Tabel 7.

Penyesuaian peran

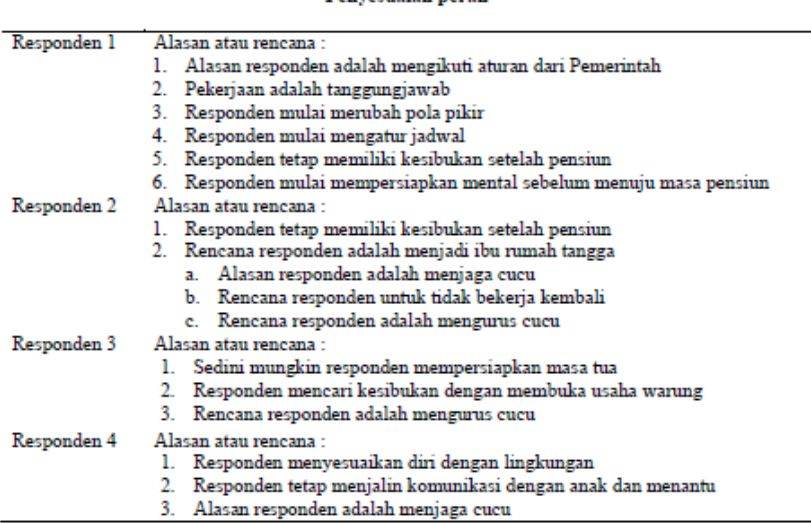

\section{Kegiatan waktu luang}

Perencanaan kegiatan waktu luang PNS setelah memasuki masa pensiun sangat mempengaruhi kesiapan serta kondisi psikologis PNS dalam menerima statusnya sebagai pensiunan. Apsari (2012) menjelaskan bahwa penting bagi karyawan pra-pensiun dalam mempersiapkan aktivitas dan peran sosial yang akan ditekuni untuk mengisi waktu luang serta tetap memiliki keterlibatan sosial meskipun telah pensiun.

Hurlock (2006) bahwa memanfaatkan waktu luang atau mempersiapkan diri untuk hari tua yaitu dengan mencari hobi serta berusaha agar memiliki ketertarikan terhadap hobi tersebut sehingga individu memperoleh kepuasan di hari tua. Berikut gambaran rencana kegiatan PNS untuk mengisi waktu luang setelah memasuki masa pensiun :

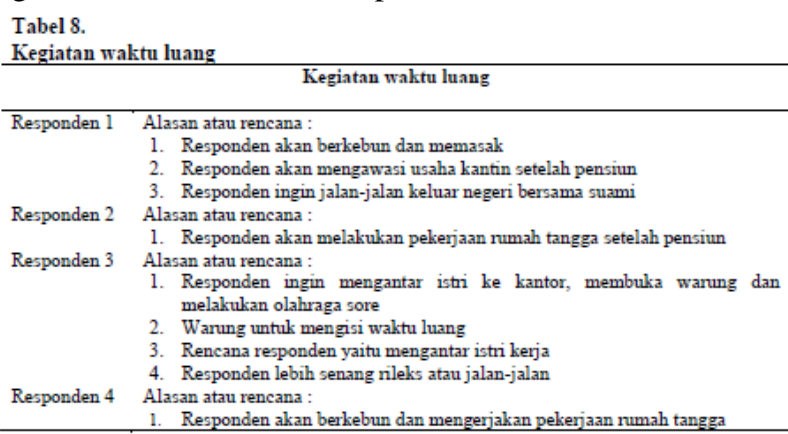

\section{Asuransi kesehatan}

Suardiman (2011) menjelaskan bahwa Pemerintah mensponsori asuransi untuk membantu kualitas hidup setelah pensiun, khususnya dalam hal kesehatan. Berdasarkan hal ini, individu yang berprofesi sebagai PNS akan mendapatkan jaminan kesehatan berupa asuransi kesehatan yang disiapkan oleh Pemerintah. Jaminan kesehatan berupa pemberian asuransi kesehatan untuk memudahkan PNS dalam memperoleh pelayanan kesehatan. Berikut gambaran jaminan kesehatan berupa asuransi kesehatan yang diperoleh PNS menjelang masa pensiun : 
Tabel 9.

Asuransi kesehatan
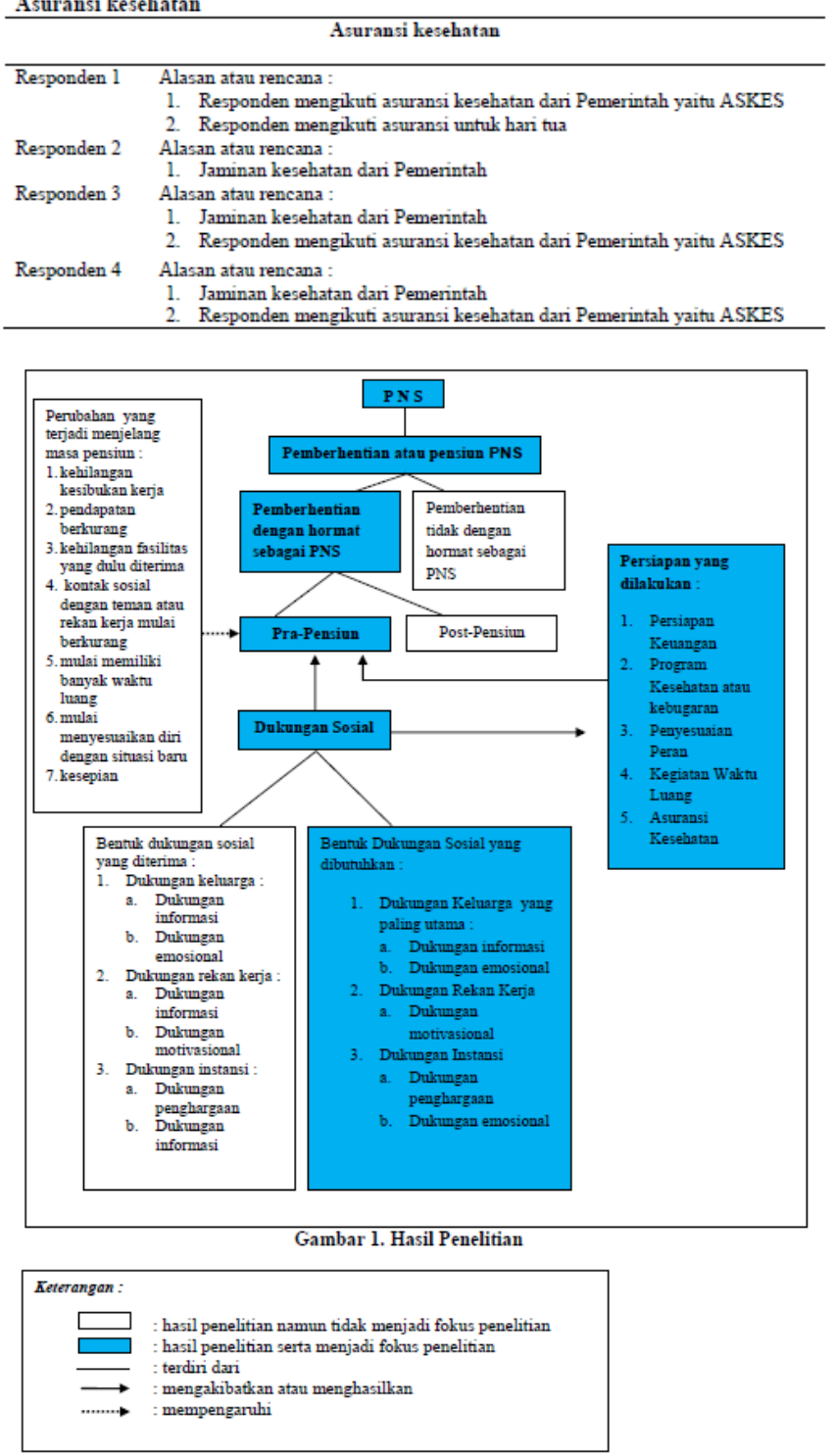

Secara garis besar, dapat disimpulkan bahwa PNS yang akan memasuki masa pensiun membutuhkan dukungan dari lingkungan yaitu dukungan yang berasal dari keluarga, rekan kerja, dan instansi. Hal ini berguna untuk mengurangi tekanan yang dialami PNS menjelang masa pensiun karena terjadi perubahan status dan peran dalam pekerjaan. Dukungan yang berasal dari keluarga merupakan dukungan paling utama yang dibutuhkan PNS menjelang masa pensiun. Adapun bentuk dukungan keluarga yang dibutuhkan PNS menjelang masa pensiun yaitu dukungan emosional dan dukungan informasi. Selain itu, PNS yang akan memasuki masa pensiun juga membutuhkan dukungan dari rekan kerja dalam bentuk dukungan motivasional dan dukungan dari instansi dalam bentuk dukungan penghargaan.

Saran praktis yang dapat diberikan berdasarkan hasil penelitian kepada PNS yang akan memasuki masa pensiun yaitu penerimaan diri bahwa pekerjaan sebagai PNS memiliki batas usia, sehingga PNS lebih mempersiapkan diri untuk memasuki masa pensiun. Dengan demikian, diharapkan agar PNS dapat menjalani masa pensiun yang baik yaitu masa pensiun yang terencana dan PNS dapat menjalani masa pensiun tanpa konflik. Selain itu, PNS mampu melakukan komunikasi secara efektif khususnya kepada keluarga terkait dengan rencana-rencana yang akan dilakukan setelah memasuki masa pensiun. Hal ini diharapkan agar dapat mengurangi tekanan yang dialami PNS menjelang masa pensiun terkait dengan perbedaan status dan peran yang akan dijalankan PNS setelah memasuki masa pensiun.

Saran praktis untuk keluarga adalah keluarga mampu memberikan dukungan kepada PNS yang akan memasuki masa pensiun dalam bentuk dukungan secara emosional seperti perhatian serta dukungan informasi melalui pemberian saran atau umpan balik untuk membantu menyelesaikan permasalahan yang dialami PNS menjelang masa pensiun seperti permasalahan dalam bidang pekerjaan. Selain itu, keluarga dapat mendukung kegiatan atau rencana yang akan dilakukan PNS setelah memasuki masa pensiun sehingga PNS lebih siap untuk menjalankan setiap kegiatan yang telah direncanakan sebelumnya. Dengan demikian, diharapkan agar PNS dapat menjalani masa pensiun yang baik yaitu masa pensiun yang terencana dan PNS dapat menjalani masa pensiun tanpa konflik.

Saran praktis bagi rekan kerja adalah rekan kerja mampu memberikan dorongan atau motivasi kepada PNS yang akan memasuki masa pensiun agar PNS lebih siap untuk memasuki masa tersebut.

Saran praktis bagi instansi adalah instansi dapat memberikan dukungan kepada PNS yang akan memasuki masa pensiun baik dalam bentuk pelatihan atau penyuluhan yang mencakup seluruh PNS menjelang masa pensiun. Dengan demikian, diharapkan agar seluruh PNS memiliki kemampuan dan keterampilan yang dapat digunakan setelah memasuki masa pensiun.

Saran bagi peneliti selanjutnya adalah sehubungan dengan keterbatasan responden yang hanya memfokuskan pada usia PNS yaitu dua tahun sebelum memasuki masa pensiun, maka penelitian selanjutnya dapat membahas bentukbentuk dukungan sosial serta persiapan-persiapan PNS menjelang masa pensiun yang dilihat dari golongan serta jabatan PNS sehingga diperoleh pembahasan yang lebih komprehensif.

\section{DAFTAR PUSTAKA}

Aditya, Ivan. (2013, Oktober 16). PNS tidak disiplin meningkat. Diakses pada Desember 14, 2013, dari http://krjogja.com/read/190544/pns-tidak-disiplinmeningkat.kr.

Apsari, F. Y. (2012). Pengembangan model persiapan pensiun bagi karyawan non-kependidikan di universitas X. Surabaya: Fakultas Psikologi Universitas Katolik Widya Mandala. 
Azizah, L. M. (2011). Keperawatan lanjut usia. Yogyakarta: Graha Ilmu.

Beritametro. (2013, September 13). Mimpi jadi PNS, wani piro?. Diakses pada Desember 14, 2013, dari http://www.beritametro.co.id/fokus/mimpi-jadi-pns-wanipiro.

Bjorklund, B. R., \& Bee, H. L. (2009). The journey of adulthood. New Jersey: Prentice Hall.

BKN. (2010, Maret 24). Pemberhentian PNS. Diakses padaOktober 14, 2013, from www.bkn.go.id: http://www.bkn.go.id/in/peraturan/pedoman/pedomanberhenti-pns.html.

BPS. (2013). Bali dalam angka 2013. Bali: BPS Provinsi Bali.

Burger, J. M. (2008). Personality (seventh edition). Wadsworth: Cengage Learning.

Chrismawati, F. (2008). Motivasi untuk sembuh pada remaja penyalahguna narkoba ditinjau dari dukungan sosial. Semarang: Fakultas Psikologi Universitas Katolik Soegijapranata.

Christiana, D. I. (2008). Dukungan sosial dan konsep diri sebagai prediktor bagi kemampuan bergaul pada remaja. Semarang: Fakultas Psikologi Universitas Katolik Soegijapranata.

Creswell, J. W. (2009). Research design pendekatan kualitatif, kuantitatif, dan mixed. Yogyakarta: Pustaka Pelajar.

Dewi, A. K. (2011). Hubungan antara kecerdasan emosi dengan kecemasan menghadapi masa pensiun pada pegawai negeri sipil. Surakarta: Program Studi Psikologi Fakultas Kedokteran Universitas Sebelas Maret.

Gunarsa, S. D., \& Gunarsa, Y. D. (1995). Psikologi perawatan. Jakarta: PT. BPK Gunung Mulia.

Gunawan, Imam. (2013). Metde penelitian kualitatif teori \& praktik. Jakarta: Bumi Aksara.

Haber, D. (2010). Health promotion and aging . New York: Springer publishing company.

Hurlock, E. B. (2006). Psikologi perkembangan suatu pendekatan sepanjang rentang kehidupan (edisi kelima). Jakarta: Erlangga.

Imama, H. (2011). Hubungan antara kecerdasan emosi dan dukungan sosial dengan kecemasan menghadapi masa pensiun. Jakarta: Universitas Islam Negeri Syarif Hidayatullah.

Iskandar. (2009). Metodologi penelitian kualitatif. Jakarta: Gaung Persada (GP Press).

Kabartop. (2012, Mei 25). Miris! Rata-rata 3 PNSper hari ke poli jiwa menjelang pensiun. Diakses pada Oktober 25, 2013, Dari kabartop.com: http://kabartop.com/miris-rata-rata-3pns-per-hari-ke-poli-jiwa-menjelang-pensiun/.

Kadarisman, M. (2011). Menghadapi pensiun dan kesejahteraan psikologis pegawai negeri sipil. Jurnal Kebijakan dan Manajemen PNS volume 5 nomer 2.

Kintaninani, A. (2013). Kebermaknaan hidup pegawai dalam menghadapi pensiun. Yogyakarta: Fakultas Ilmu Sosial Dan Humaniora Universitas Islam Negeri Sunan Kalijaga.

Kristiono, E. Y. (2011). Kecemasan menghadapi menopause ditinjau dari dukungan sosial suami. Semarang: Fakultas Psikologi Universitas Katolik Soegijapranata.

Maulia, D. (2006). Penyesuaian sosial anak berbakat ditinjau dari tingkat keberbakatan dan dukungan sosial orangtua.
Semarang: Fakultas Psikologi Universitas Katolik Soegijapranata.

Moleong, L. J. (2004). Metodologi penelitian kualitatif . Bandung: PT Remaja Rosdakarya.

Monks, F., Knoers, A., \& Haditono, S. R. (2006). Psikologi perkembangan. Yogyakarta: Gadjah Mada University Press.

Murtiningrum, A. (2005). Analisis pengaruh konflik pekerjaankeluarga terhadap stress kerja dengan dukungan sosial sebagai variabel moderasi (Studi kasus pada guru kelas 3 SMP Negeri di Kabupaten Kendal). Semarang: Program Studi Magister Manajemen Program Pascasarjana Universitas Diponegoro.

Nopariawan, K. (2014, Februari 6). Jumlah CPNS di Bali. (W. D. Sekarsari, Interviewer)

Noviani, N. L. (2007). Motivasi menjadi pegawai negeri sipil (PNS) pada WNI keturunan India (Studi kualitatif pada komunitas koja di Kota Semarang). Semarang: Fakultas Psikologi Universitas Diponegoro.

Nurlailiwangi, E., Rahayu, M. S., \& Juwita, O. (2011). Studi mengenai dukungan sosial orangtua dalam melatih "Self Help" anak yang mengalami "Down Syndrome" di PKA PUSPPA Suryakanti Bandung. Prosiding Seminar Nasional Penelitian dan PKM : Sosial, Ekonomi, dan Humaniora, 6774.

Oktavianus. (2011). Koping perawat usia madya (50-55 tahun) menghadapi pensiun di RSUD Kabupaten Sukoharjo. Jurnal Kesmadaska volume 2 nomer 1, 17-26.

Olson, D. H., \& DeFrein, J. (2000). Marriages and families. New York: McGraw-Hill.

Papalia, D. E., Olds, S. W., \& Feldman, R. D. (2009). Human development. New York: McGraw-Hill.

Papalia, D. E., Sterns, H. L., Feldman, R. D., \& Camp, C. J. (2007). Adult development and aging. New York: McGraw-Hill.

Pieter, H. Z., \& Lubis, N. L. (2011). Pengantar psikologi untuk kebidanan. Jakarta: Kencana.

Poerwandari, E. (1998). Pendekatan kualitatif dalam penelitian psikologi. Jakarta: Lembaga Pengembangan Sarana Pengukuran dan Pendidikan Psikologi (LPSP3) Fakultas Psikologi Universitas Indonesia.

Rio. (2013, April 24). Pensiun sebagai pegawai negeri sipil dengan bahagia. Diakses pada Mei 7, 2014, dari www.bppk.depkeu.go.id: http://www.bppk.depkeu.go.id/bdk/pekanbaru/index.php?o ption $=$ com_content $\&$ view=article $\&$ id=266:pensiunsebagai-pegawai-negeri-sipil-denganbahagia\&catid=10:umum

Santrock, J. W. (2002). Remaja. Jakarta: Erlangga.

Sarafino, E. (1998). Health psychology. New York: John Wiley and Sons.

Setyaningsih, L. (2007). Stres kerja pada guru ditinjau dari dukungan sosial dan masa kerja. Semarang: Universitas Soegijapranata.

Strauss,A., \& Corbin,J. (2003). Dasar-dasar penelitian kualitatif. Yogyakarta: Pustaka Pelajar.

Suardiman, S. P. (2011). Psikologi usia lanjut. Yogyakarta: Gadjah Mada University Press. 
Sugiyono. (2012). Metode penelitian kuantitatif, kualitatif, dan r\&d. Bandung: Alfabeta.

Syafrudin, A. (2012, Januari 19). Kenapa PNStidak produktif. Diakses pada Desember 14, 2013, dari alfanaini.blogspot.com:

http://alfanaini.blogspot.com/2012/01/kenapa-pns-tidakproduktif.html.

Taylor, S. E., Peplau, L. A., \& Sears, D. O. (2009). Psikologi sosial. Jakarta: Kencana.

Tohirin. (2012). Metode penelitian kualitatif dalam pendidikan dan bimbingan konseling. Jakarta: PT Rajagrafindo Persada.

Wahyu, T. K. (2007). Kecemasan wanita karier terhadap peran ganda ditinjau dari dukungan sosial suami. Semarang: Fakultas Psikologi Universitas Soegijapranata.

Yunian, F. A. (2013). Pengaruh optimisme menghadapi masa pensiun terhadap post power syndrome pada anggota badan pembina pensiunan pegawai (BP3) pelindo Semarang. Semarang: Universitas Negeri Semarang. 